\title{
Improvement of Hematopoietic and Immunologic Findings in Sublethal Gamma Irradiated Rats Treated with Bone Marrow Transplantation and Wheat Germ Oil
}

\author{
Maha G. Soliman', Omaima M. Ashry², Mervat A. E. Ahmed1', Yasmine H. Abd El-Naby ${ }^{1}$ \\ ${ }^{1}$ Zoology Department, Faculty of Science, Al-Azhar University for Girls, Cairo, Egypt \\ ${ }^{2}$ Radiation Biology Department, National Center for Radiation Research and Technology (NCRRT), Cairo, Egypt \\ Email: jasy jasy85@yahoo.com
}

Received 30 March 2015; accepted 12 May 2015; published 15 May 2015

Copyright @ 2015 by authors and Scientific Research Publishing Inc.

This work is licensed under the Creative Commons Attribution International License (CC BY).

http://creativecommons.org/licenses/by/4.0/

(c) (i)

\section{Abstract}

The objective of this study was to evaluate the efficacy of the wheat germ oil (WGO) and bone marrow transplantation (BMT) in boosting the immuno response and protecting from oxidative stress in irradiated rats. BM was given by intravenous injection to male rats, one hour post gamma irradiation at the dose level of $5 \mathrm{~Gy}$. Rats were orally administrated with $54 \mathrm{mg} / \mathrm{Kg}$ body wt of wheat germ oil daily for 2 weeks before irradiation. After 14 days, results revealed that total body irradiation induced significant decreases in RBCs, WBCs and lymphocytes, as well as Glutathione (GSH) and zinc superoxide dismutase (Zn/SOD), splenocyte count, bone marrow lymphocyte count and viability. Tumor necrosis factor alpha (TNF- $\alpha$ ) and interleukin 2 (IL-2) also recorded significant decrease while interleukin 6 (IL-6) and lipid peroxidation marker malondialdehde (MDA) in serum and spleen were conversely elevated. In irradiated animals receiving BMT and WGO, values of MDA in serum and tissue were significantly depressed as compared with the irradiated group, while lymphocytes, bone marrow viability percentage, splenocytes percentage, IL-2, IL-6 and GSH were significantly elevated. The curative action of WGO enforcing significant innate response could trigger and augment adaptive immune response by BMT, thus protecting immune system from radiation induced damage as well as oxidative stress.

\section{Keywords}

BMT, Gamma Irradiation, WG0, Immune Response 


\section{Introduction}

Ionizing radiation works by damaging the DNA of exposed tissue leading to cellular death [1]. Interaction of ionizing radiation with living cells causes a variety of changes depending on kind of exposure, absorbed dose, duration of exposure, interval after exposure and also susceptibility in tissues [2]. Most of cellular alterations induced by ionizing radiation are mediated by the generation of free radicals and related reactive species, mainly derived from oxygen [3]. The overproduction of reactive oxygen species (ROS) in cells and tissues increases oxidative stress that may induce damages to lipids, protein oxidation, DNA and RNA [4].

Hematopoietic stem cell transplantation (HSCT) is the infusion of hematopoietic stem cell from a donor into a patient who has received chemotherapy or irradiation dose that can be marrow ablative [5]. Peripheral blood stem cells are now the most common source of stem cells for allogeneic HSCT [6]. Irradiated mice followed by transplantation of stem cells of the immune system became much-used method that fostered the burgeoning field of cellular immunology. Therefore, those who received HSCT belonged to immuno-compromised patient population [7].

In recent years, essential oils and extracts of many plant species have become popular in many pharmaceutical and food processing applications [8]. Natural radio protectors such as WG and oil seeds are found in plant materials [9]. Wheat is an important source of vitamins, minerals, dietary fibre and phyto-chemicals. The oil is a rich source of tocopherols and tocotrienols. The germ is the most nutritious portion of the wheat and it makes up about $2.5 \%$ of the grain weight. Wheat germ is a rich source of vitamins B complex and E [10] [11]. Vitamin E acts as inhibitor of oxidation processes in body tissues. It protects cells against the effects of free radicals that can cause cell damage and contribute to the development of cancer [12]. Wheat germ oil not only prevents autoxidation of unsaturated fatty acids but also generates DNA protective properties [13] [14]. Hence, it would be beneficial to determine immune-stimulating and the radio protective effects of wheat germ oil.

This work aims to investigate the boosting of innate immunity by the administration of wheat germ oil enforcing adaptive immune response and bone marrow transplanted to irradiated animals.

\section{Materials and Methods}

Mature male albino rats of pure strain (Rattus albinus) weighing 110 - $150 \mathrm{~g}$ were obtained from the animal house of the National Center for Radiation Research and Technology (NCRRT), Atomic Energy Authority, Egypt. Animals were housed in especially designed cages, six males per cage. All rats were kept under normal conditions of light and darkness, allowed free access to drinking water and normal rodent diet in the form of pelleted concentrated diet. Animal were kept to acclimatize for a week before the onset of the experiment.

All animal treatments were conducted according to the Ethics committee of the National Research Center and in accordance with the recommendations for the proper case and use of laboratory animals (HN publication No. 85-23, revised 1985) in accordance with international ethical considerations.

Groups of ten rats were dissected under light anesthesia and blood sample were collected by heart puncture using sterile syringes. Part of the blood was collected in heparinized tubes to determine RBCs and WBCs counts using a haemocytometer and lymphocytes were determined according to Dacie and Lewis (1993) [15]. Reduced GSH and Zn/SOD content were measured according to Beutler et al. (1963) and Yoshioka et al. (1979) [16] [17] respectively. The rest of the blood was used to obtain serum for MDA measurement according to Yoshioka et al. (1979) [17]. IL-2 and IL-6 concentrations were determined by using enzyme linked immunosorbent assay (ELISA). ELISA kits for IL-2 and IL-6 were obtained from Kanya Biomedical Company Gateway Seatle and measured according to Chan and Perlstein (1987) and Kaminska et al. (2000) [18] [19] respectively, while TNF- $\alpha$ concentration was assayed by commercially available ELISA kit (Quantikine, R \& D Systems, Minneapolis, MN) and measured according to Aramachi (1988) [20]. A sample of spleen tissue was homogenized to estimate MDA (Yoshioka et al., 1979) [17]. Determination of viable bone marrow, bone marrow lymphocyte and splenocyte percentages were performed according to Esser et al. (2001), Sinai et al. (1978) and Takabatake et al. (1997) [21]-[23] respectively.

\subsection{Irradiation}

Whole body irradiation was performed using Gamma-Cell 40 (Cesium-137) biological irradiator manufactured by Canada Ltd. source situated at NCRRT. Animals were irradiated at an acute single sublethal dose of 5 Gy at a 
dose rate of 1.2 rad per second. Sarkar et al. (1988) [24] declared that 8 Gy is considered a lethal dose for rats.

\subsection{Bone Marrow Transplantation}

Donors and recipients were chosen of the same inbred strain, brother to brother (syngeneic transplantation). Femur bones were dissected out and cleaned. The ends of the bones were chipped by a bone nibbling forceps. Then the marrow was blown out of the femur into isotonic saline solution under sterilized conditions inside a laminar flow cabinet. The marrow was collected into a sterile container surrounded by ice cubes, and mixed by drawing and expelling it several times from the syringe without needle in order to avoid mechanical damage to the cells. The total viable cells of about $75 \times 10^{6} \pm 5 \%$ were injected intravenously (i.v.) 1 hour after irradiation [25].

\subsection{Wheat Germ Oil Supplementation}

Wheat germ oil (WGO) was supplied as a soft gel from Sigma Chemical Company. WGO was freshly prepared just before the application. WGO $(300 \mathrm{mg} / 5 \mathrm{ml})$ was suspended in corn oil and administered to animals by oral gavage at doses of $54 \mathrm{mg} / \mathrm{kg}$ body weight. The doses used in this study were selected on the basis of the reports of previous studies [26] [27].

Animals were divided into:

1) Normal control male rats (C).

2) Group of male rats injected with BMT $\left( \pm 75 \times 10^{6}\right)$ cells through the caudal vein $\left(\mathrm{C}_{\mathrm{BM}}\right)$.

3) Group of male rats injected orally with $54 \mathrm{mg} / \mathrm{Kg}$ body weight of wheat germ oil as a single daily dose for 14 successive days $\left(\mathrm{C}_{\mathrm{WGO}}\right)$.

4) Group of male rats exposed to 5 Gy whole body gamma rays (R).

5) Group of male rats exposed to 5 Gy gamma rays and received BMT one hour after irradiation (R + BM).

6) Group of male rats injected orally with $54 \mathrm{mg} / \mathrm{Kg}$ body weight of the wheat germ oil as a single daily dose for 14 successive days before irradiation ( $\mathrm{R}+\mathrm{WGO}$ ).

7) Group of male rats injected orally with $54 \mathrm{mg} / \mathrm{Kg}$ body weight of wheat germ oil as a single daily dose for 14 successive days before irradiation and received BMT one hour after irradiation ( $+\mathrm{BM}+\mathrm{WGO})$.

All animal groups were sacrificed after 14 days of irradiation.

The results were analyzed using one way analysis of variance (ANOVA) followed by Duncan's test according to Steel and Tosrie (1980) [28].

\section{Results}

Irradiation of animals at 5 Gy induced a significant depression $(\mathrm{P}<0.05)$ in RBCs, WBCs, lymphocytes, bone marrow lymphocytes and viability and splenocytes. BMT and/or WGO together with irradiation showed a significant elevation $(\mathrm{P}<0.05)$ in RBCs, WBCs, lymphocytes, bone marrow lymphocytes and viability and splenocytes as compared to irradiated group (Table 1 and Figure 1 ).

A significant decrease was noticed in serum IL-2 and TNF- $\alpha$ values $(\mathrm{P}<0.05)$ while IL-6 level recorded a significant increase post $5 \mathrm{~Gy}$ gamma irradiation. All treated irradiated groups showed significant increase in IL-2, TNF- $\alpha$ levels while IL-6 level recorded a significant decrease when compared to the irradiated group (Figure 2 and Table 2).

Results presented in Table 3 demonstrated a significant decrease of blood GSH and $\mathrm{Zn} / \mathrm{SOD}(\mathrm{P}<0.05)$ and a significant increase $(\mathrm{P}<0.05)$ of serum and spleen MDA two weeks post exposure to 5Gy gamma radiation. Each of BMT and/or WGO treatment combined with irradiation induced a significant elevation of GSH (P < $0.05)$ and $\mathrm{Zn} / \mathrm{SOD}$ and a significant decrease of serum and spleen MDA $(\mathrm{P}<0.05)$ as compared to irradiated group.

\section{Discussion}

Ionizing radiation causes defective haemopoiesis according to radiation dose rate and quality [29]. This is followed by thrombocytopenia and concomitant hemorrhages beside effects in adaptive immune system resulting from deficient lymphopoiesis and apoptosis of lymphocytes [30]. Proliferation of stromal cells and bone-marrow stromal layer formation are sensitive to radiation in vitro, while established bone-marrow stromal layer is relatively resistant to radiation [31]. Since the bone marrow is a primary target for irradiation, the recovery was de- 
Table 1. Effect of BMT and WGO supplementation on some blood parameters, BM percentage and viability and splenocyte percentage in irradiated and non-irradiated rats.

\begin{tabular}{|c|c|c|c|c|c|c|}
\hline Groups & $\begin{array}{c}\text { RBCs } \\
\left(10^{6} / \mathrm{mm}^{3}\right)\end{array}$ & WBCs $\left(10^{3} / \mathrm{mm}^{3}\right)$ & $\begin{array}{c}\text { Lymphocytes } \\
\text { (\%) }\end{array}$ & $\begin{array}{c}\text { Bone marrow } \\
\text { lymphocyte count } \\
(\%)\end{array}$ & $\begin{array}{l}\text { Viable bone } \\
\text { marrow count } \\
(\%)\end{array}$ & $\begin{array}{c}\text { Splenocyte } \\
\text { (\%) }\end{array}$ \\
\hline Control & $7.32 \pm 0.38$ & $6.04 \pm 0.57$ & $44.8 \pm 0.37$ & $20.4 \pm 0.5$ & $66.4 \pm 0.5$ & $77 \pm 0.7$ \\
\hline $\mathbf{C}_{\text {BM }}$ & $6.92 \pm 0.31$ & $5.14 \pm 0.42$ & $37.4 \pm 0.73 \mathrm{c}$ & $21 \pm 0.7$ & $65 \pm 0.7$ & $74.6 \pm 1.2$ \\
\hline $\mathrm{C}_{\mathrm{WGO}}$ & $6.46 \pm 0.4$ & $5.64 \pm 0.61$ & $37.6 \pm 0.67 \mathrm{c}$ & $19.8 \pm 0.37$ & $63.2 \pm 1.06$ & $76.2 \pm 0.58$ \\
\hline $\mathbf{R}$ & $5 \pm 0.3 \mathrm{c}$ & $2.52 \pm 0.46 \mathrm{c}$ & $22.2 \pm 0.86 \mathrm{c}$ & $13.4 \pm 0.5 \mathrm{c}$ & $41.2 \pm 0.58 \mathrm{c}$ & $44.4 \pm 1.91 \mathrm{c}$ \\
\hline $\mathbf{R}+\mathbf{B M}$ & $6.18 \pm 0.27 \mathrm{r}$ & $3.52 \pm 0.45 \mathrm{c}$ & $31.4 \pm 0.25 \mathrm{c} \mathrm{r}$ & $16.16 \pm 0.60 \mathrm{c} \mathrm{r}$ & $50.4 \pm 0.51 \mathrm{c} \mathrm{r}$ & $52.4 \pm 0.81 \mathrm{c} \mathrm{r}$ \\
\hline R + WGO & $6.16 \pm 0.45 \mathrm{r}$ & $5.26 \pm 0.35 \mathrm{r}$ & $37.2 \pm 0.38 \mathrm{c} \mathrm{r}$ & $16.8 \pm 0.37 \mathrm{c} \mathrm{r}$ & $51.4 \pm 0.67 \mathrm{c} \mathrm{r}$ & $52.6 \pm 0.66 \mathrm{c} \mathrm{r}$ \\
\hline R + BM + WGO & $6.38 \pm 0.38 \mathrm{r}$ & $5.25 \pm 0.51 \mathrm{r}$ & $40.4 \pm 0.5 \mathrm{c} \mathrm{r}$ & $18.4 \pm 0.24 \mathrm{c} \mathrm{r}$ & $61.2 \pm 0.58 \mathrm{c} \mathrm{r}$ & $62.6 \pm 0.92 \mathrm{c} \mathrm{r}$ \\
\hline
\end{tabular}

Table 2. Effect of BMT and WGO supplementation on IL-2, IL-6 and TNF- $\alpha$ in irradiated and non-irradiated rats.

\begin{tabular}{|c|c|c|c|}
\hline Groups & $\begin{array}{c}\text { IL-2 } \\
(\mathrm{pg} / \mathrm{ml})\end{array}$ & $\begin{array}{c}\text { IL-6 } \\
(\mathrm{pg} / \mathrm{ml})\end{array}$ & $\begin{array}{l}\text { TNF- } \alpha \\
(\mathrm{pg} / \mathrm{ml})\end{array}$ \\
\hline Control & $165.8 \pm 1.24$ & $164.4 \pm 1.8$ & $353.2 \pm 2.15$ \\
\hline $\mathrm{C}_{\mathrm{BM}}$ & $178 \pm 1.41 \mathrm{c}$ & $172.8 \pm 2.81 \mathrm{c}$ & $344 \pm 1.76 \mathrm{c}$ \\
\hline $\mathrm{C}_{\mathrm{WGO}}$ & $162 \pm 0.89$ & $164.6 \pm 1.81$ & $353 \pm 1.14$ \\
\hline $\mathbf{R}$ & $118.6 \pm 1.36 \mathrm{c}$ & $301.8 \pm 2.51 \mathrm{c}$ & $185 \pm 1.7 \mathrm{c}$ \\
\hline $\mathbf{R}+\mathbf{B M}$ & $108.2 \pm 1.39 \mathrm{c} \mathrm{r}$ & $256 \pm 2.38 \mathrm{c} \mathrm{r}$ & $254 \pm 1 \mathrm{c} \mathrm{r}$ \\
\hline $\mathbf{R}+\mathbf{W G O}$ & $137 \pm 1.14 \mathrm{c} \mathrm{r}$ & $237 \pm 2.34 \mathrm{c} \mathrm{r}$ & $220 \pm 2.62 \mathrm{cr}$ \\
\hline $\mathbf{R}+\mathbf{B M}+\mathbf{W G O}$ & $146.6 \pm 2.42 \mathrm{c} \mathrm{r}$ & $206 \pm 1.94 \mathrm{c} \mathrm{r}$ & $304.6 \pm 2.06 \mathrm{c} \mathrm{r}$ \\
\hline
\end{tabular}

Values are expressed as mean \pm SE. c: Significant difference compared to control. r: Significant difference compared to R group.

Table 3. Effect of BMT and /or WGO supplementation on whole blood GSH and ZN/SOD, serum and spleen MDA in irradiated and non-irradiated rats.

\begin{tabular}{|c|c|c|c|c|}
\hline Groups & $\begin{array}{c}\text { GSH } \\
(\mathrm{mg} / \mathrm{ml})\end{array}$ & $\begin{array}{c}\text { MDA } \\
(\mu \mathrm{mol} / \mathrm{ml})\end{array}$ & $\begin{array}{c}\text { MDA } \\
\text { n mol/g tissue }\end{array}$ & $\mathrm{Zn} / \mathrm{SOD}(\mu \mathrm{g} / \mathrm{ml})$ \\
\hline $\mathbf{C}$ & $31.2 \pm 0.58$ & $37 \pm 0.7$ & $40.8 \pm 0.73$ & $4.62 \pm 0.39$ \\
\hline $\mathrm{C}_{\mathrm{BM}}$ & $29.8 \pm 0.58$ & $40 \pm 1 c$ & $50 \pm 1 c$ & $4.24 \pm 0.2$ \\
\hline $\mathrm{C}_{\text {WGO }}$ & $30.4 \pm 0.5$ & $36.8 \pm 0.86$ & $46.8 \pm 0.86 c$ & $4.46 \pm 0.37$ \\
\hline $\mathbf{R}$ & $10.8 \pm 0.58 \mathrm{c}$ & $62.2 \pm 0.86 \mathrm{c}$ & $70 \pm 1 c$ & $2.56 \pm 0.18 \mathrm{c}$ \\
\hline $\mathbf{R}+\mathbf{B M}$ & $16.2 \pm 0.86 \mathrm{c} \mathrm{r}$ & $46.2 \pm 1.15 \mathrm{c} \mathrm{r}$ & $53.2 \pm 1.46 \mathrm{c} \mathrm{r}$ & $3.26 \pm 0.23 c$ \\
\hline $\mathbf{R}+\mathbf{W G O}$ & $19.6 \pm 0.81 \mathrm{c} \mathrm{r}$ & $49.8 \pm 0.86 \mathrm{c} \mathrm{r}$ & $59.8 \pm 0.86 \mathrm{c} \mathrm{r}$ & $3.62 \pm 0.46 \mathrm{r}$ \\
\hline $\mathbf{R}+\mathbf{B M}+\mathbf{W G O}$ & $23.4 \pm 0.86 \mathrm{c} \mathrm{r}$ & $46 \pm 0.89 \mathrm{c} \mathrm{r}$ & $56 \pm 0.89 \mathrm{c} \mathrm{r}$ & $3.78 \pm 0.35 \mathrm{r}$ \\
\hline
\end{tabular}

Values are expressed as mean \pm SE. c: Significantly different compared to control. r: Significantly different compared to $\mathrm{R}$ group $(\mathrm{P}<0.05)$.

pendent on extramedullary cell division in the thymus and spleen [32]. Whole body gamma irradiation causes considerable decrease in the hematological values like erythrocytes, leukocytes and lymphocytes [33] [34]. Decrease in the number of erythrocytes in the present study was imputed to depletion of erythroblast differentiation and reticulocyte release from the bone marrow and the loss of cells from the circulation by hemorrhage [35] [36]. In the present study, lymphocytes were decreased in irradiated group compared to the control group. Depletion 


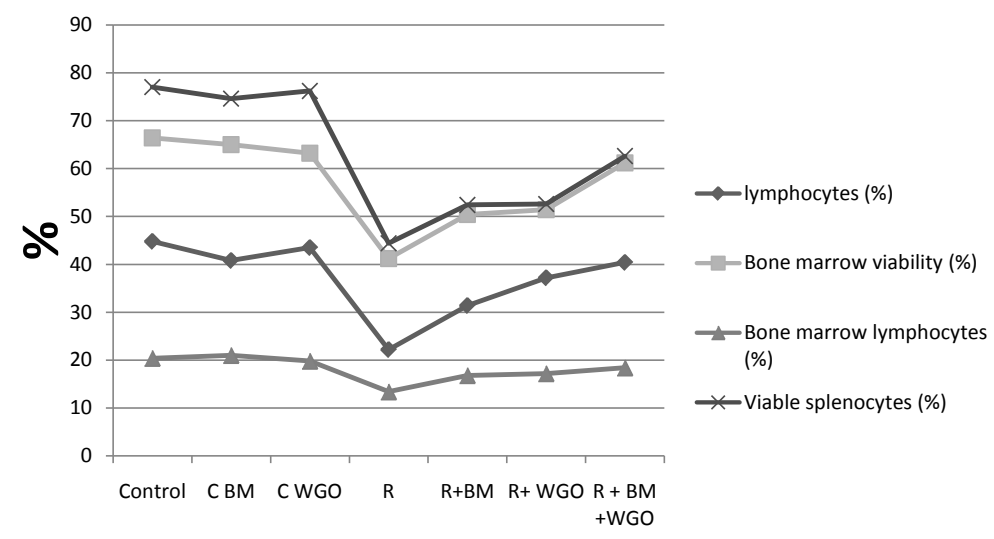

Figure 1. Effect of BMT and WGO supplementation on blood lymphocytes, bone marrow viability, bone marrow lymphocytes and viable spleenocytes percentages in irradiated and non-irradiated rats.

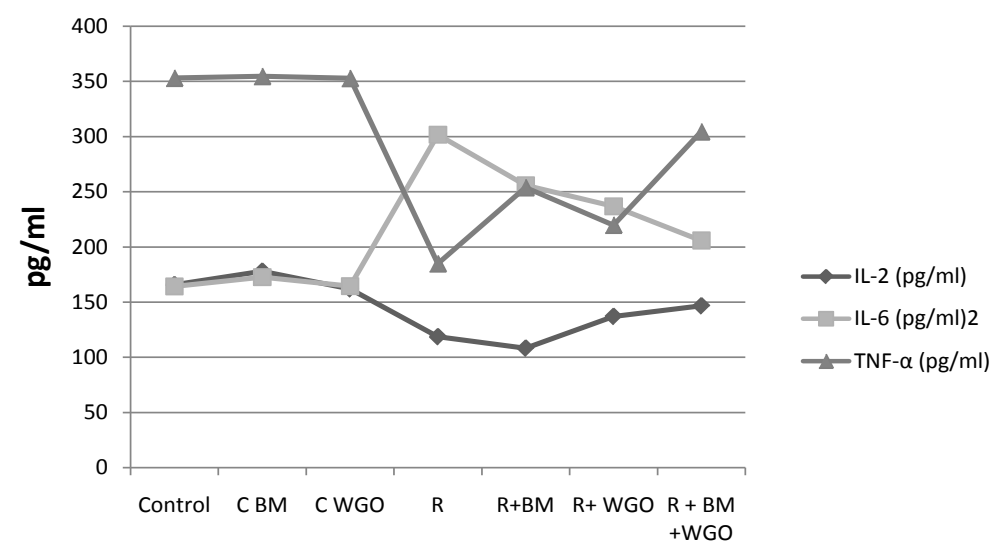

Figure 2. Effect of BMT and WGO supplemintation on IL-2, IL-6 and TNF- $\alpha$ in irradiated and non-irradiated rats $(\mathrm{pg} / \mathrm{ml})$.

of lymphocytes induced by irradiation is attributed to apoptosis and necrotic death [37].

Leukocytes and lymphoid organs are also highly sensitive to radiation and oxidative stress [38]. Radiation does not only affect cell growth, proliferation, viability and migration capacity of stem cells but also acts as a promoter of apoptosis [39]. In individuals exposed to high doses of radiation, both mature lymphocytes and bone marrow stem cells were severely damaged, causing profound depletion of granulocytes and natural killer cells, which together defend against microbial invasion, causing death from active infections [30]. These previous investigations may explain the significant decline in both bone marrow lymphocyte count and viability.

IL-2 plays an important role in growth, proliferation, and differentiation of T cells [40]. In agreement with literature, the present study demonstrated decreased IL-2 level in irradiated animals. Bass et al. (1989) [41] demonstrated that $\mathrm{T}$ lymphocytes in spleen cells of total lymphoid irradiated (TLI) mice, secrete $5 \%-9 \%$ of the mean normal level of IL-2. Other investigations show that T cells from TLI-treated mice produce more IL-4 and less IL-2 and IFN- $\gamma$ than normal counterparts [42] [43]. Gamma irradiation is known to significantly inhibit the proliferation of effective T cells by reducing the levels of Th1 type cytokines (such as IL-2) [44]. Post irradiation in the present study, IL-6 levels showed a significant increase compared to the control group which comes in agreement with Chang et al. (1997) [45]. Ionizing radiation induced DNA damage have been shown to initiate the expression of various circulatory cytokines such as IL- 6 and some of these responses may be related to apoptosis. IL-6 itself is a pluripotent cytokine which is involved in acute pro-inflammatory process associated with overexposure to ionizing radiation [46]. The present results showed that $5 \mathrm{~Gy}$ gamma irradiation induced a significant decrease of TNF- $\alpha$, which is in agreement with Tsukimoto et al. (2009) [47]. The previous authers proved the anti-inflammatory effects of gamma irradiation followed by suppression of TNF- $\alpha$ production in cells 
of mouse macrophages cell line. TNF induced by irradiation could regulate the BM cells apoptosis in vitro and in vivo which is a crucial event in BM dysfunction [48].

The present results demonstrated a significant reduction in blood GSH and $\mathrm{Zn} / \mathrm{SOD}$ as well as elevation in serum and spleen MDA by irradiation. This could be attributed to enhanced utilization of the antioxidant system in an attempt to detoxify radiation generated free radicals [49]. The decrease in the activity of antioxidant enzymes might result from radiation-induced cell membrane damage and alterations in dynamic permeability of membranes due to peroxidation, which is followed by the release of intracellular enzymes to the blood stream [50]. It also could be attributed to their utilization by the enhanced production of ROS [51].

The present results discerned that injection of BMT alone post irradiation lead to a significant elevation of RBCs and lymphocytes as compared to the irradiated group. BMT post irradiation showed elevation of splenocytes, bone marrow lymphocyte count and viability due to proliferation of stromal cells [31]. Protection of BMT from death associated with bone marrow failure caused by irradiation may be provided by systemic stimulation of the remaining intact hematopoietic stem cells that survive irradiation. The accelerated restoration of functional hematopoietic cells is believed to be the major factor in the survival of irradiated mice [52].This explains the present results which showed a significant increase in both bone marrow lymphocyte count and viability after bone marrow injection when compared with the irradiated group.

In the present study BMT to irradiated animals induced a significant reduction of IL-2 concentration compared to irradiated animals. Wang (2002) [53] explained that IL-2 concentrations in recipient mouse serum were relatively low. Because of cytokine autocrine and paracrine physiological characteristics, their expression in a microenvironment may be sufficient to reconstitute the immunological and hematopoietic depression after BMT. Also, BMT could cause the lack of IL 2-producing cells and/or the increased activity of suppressor cells of the helper function. The depression in IL-2 level in the present results supports the successful engraftment of bone marrow cells [54]. Data revealed that serum IL-6 levels decreased after BMT in irradiated rats which in agreement with Lee et al. (2002) [55]. IL-6 plays a primary role in hematopoiesis as it regulates the differentiation of B cells, megakaryocytes and platelets [56]. IL-6 might mitigate acute graft versus host disease (GVHD) without losing the significant antitumor benefits of allogeneic BMT [57]. The hypothesis suggested that the protection of mice from radiation-induced hematopoietic death is mediated by cytokines and chemokines [57]. The amelioration of serum TNF levels of irradiated rats after BMT may be related to absence of the immunological reaction against non-HLA allogeneic antigens as a result of the immunosuppressive effect of irradiation [58]. Furthermore, neutralization of TNF- $\alpha$ have been reported by Brown and Thiele (2000) [59] to reduce complications after BMT.

It is well documented that total body irradiation (TBI) followed by BMT, has been shown to raise the erythropoietic activity in both bone marrow and spleen [60] [61]. Accordingly, it causes elevation in red blood cells, the important source of GSH and can ameliorate the GSH depletion in blood and organs and hence oxidative stress [62]. These findings coinside with present results where the GSH was elevated significantly compared to the irradiated group post BMT.

The present data discerned that administration of wheat germ oil led to an elevation in RBCs, bone marrow lymphocytes and viability as compared to the irradiated group after 2 weeks. These results are greatly supported by Adaramoye et al. (2010) [63] who noticed that the treatment of rats with wheat germ oil at $54 \mathrm{mg} / \mathrm{kg}$ body wt prior to whole body $\gamma$-irradiation seems to exert protective effects. The mechanism by which wheat germ oil mediated its effects may be by inhibiting free radical liberation or scavenging these free radicals causing reduction of the damage induced in bone marrow cells. Vinod et al. (2012) [64] demonstrated that wheat germ oil stimulated splenocyte proliferation in vitro in a concentration-dependent manner and suppress the cellular and humoral response. This comes in accordance with our results that administration of WGO before gamma irradiation causes an elevation in splenocyte percentage.

Zeinab et al. (2010) and Ibrahim et al. (2011) [65] [66] proved that gamma radiation exposure results in varying degrees of oxidative stress and hematological parameters of blood were increased with WGO pre-treatment.

The production of IL-2 was significantly increased with the administration of WGO before gamma irradiation which comes in accordance with the previous study [67]. WGO was found to prolong the Th1 response to enhance IL-2 production [68]. Wheat germ oil supplementation causes a drop in serum level of IL-6 and may help reduce cancer risk by acting as an antioxidant and by preventing formation of carcinogenic nitrosamines formed in the stomach from nitrites in foods [69]. WGO appears to be effective in reducing free radical oxidative dam- 
age induced by gamma irradiation [70]. In the present study, WGO supplementation as a radioprotector induced an elevation in TNF- $\alpha$ level in irradiated animals. This elevation may be due to the WGO pro-inflammatory cellular actions that include stimulating the production of collagenases and increasing the expression of adhesion molecules necessary for leukocyte extravasation [71].

Paranich et al. (2000) [26] showed that in oral administration WGO efficiently saturates the body with vitamin $\mathrm{E}$ which improves the flow of blood and strengthens the veins and capillaries. These are free radical scavengers and might increase intracellular glutathione (GSH) stores [72]. Vitamin E also known to enhance the body's immune response, inhibits nitrosamine formation, enhances cell communication and inhibits the metabolic activation of carcinogen [73] [74]. Vitamin E can effectively counteract ROS generated by toxicant or carcinogen induced oxidative damage by trapping reactive oxyradicals and preserve membrane integrity [75]. Results of this study demonstrated that WGO exerted a positive effect on oxidative stress markers and immunological response.

\section{Conclusion}

The present findings confirmed enhanced hematopoietic reconstitution, accelerated BM restoration and enhanced biological defense activities against oxidative stress via boosting adaptive and innate immunity by BMT and WGO.

\section{References}

[1] Pourhomayoun, M., Fowler, M.L. and Jin, Z. (2014) Robustness Analysis of Sparsity Based Tumor Localization under Tissue Configuration Uncertainty. IEEE Signal Processing in Medicine and Biology Symposium (SPMB12), 3, 8-15.

[2] Sankaranarayanan, A. (2006) Analysis of Radiation-Associated Changes in Gene Expression Using Microarray Technology. The British Journal of Radiology, 26, 131.

[3] Maurya, D.K., Adhikari, S., Nair, C.K. and Devasagayam, P.A. (2007) DNA Protective Properties of Vanillian against $\gamma$-Radiation under Different Conditions Possible Mechanisms. Mutation Research, 7, 634-669.

[4] Ornoy, A. (2007) Embryonic Oxidative Stress as a Mechanism of Teratogenesis with Special Emphasis on Diabetic Embryopathy. Reproductive Toxicology, 7, 24-31.

[5] Bonadio, R.K., Loh, Y. and Pearce, W. (2005) Clinical Applications of Blood-Derived and Marrow-Derived Stem Cells for Nonmalignant Diseases. Journal of the American Medical Association, 299, 925-936.

[6] Atkins, H.L. and Freedman, M.S. (2013) Hematopoietic Stem Cell Therapy for Multiple Sclerosis: Top 10 Lessons Learned. Neurotherapeutics, 10, 68-76. http://dx.doi.org/10.1007/s13311-012-0162-5

[7] Van Burik, J.A. and Weisdrof, C.G. (1999) Infectious Complications Following Unrelated Cord Blood Transplantation. Bailliere's Clinical Infectious Diseases, 92, 289-296.

[8] Cowan, M.M. (1999) Plant Products as Antimicrobial Agents. Clinical Microbiology Reviews, 12, 564-582.

[9] Singh, K., Parekh, I., Brown, S., Kao, T. and Mog, R. (2010) Tocopherol Succinate: Modulation of Antioxidant Enzymes and Oncogene Expression, and Hematopoietic Recovery. International Journal of Radiation Oncology, Biology, Physics, 79, 571-578. http://dx.doi.org/10.1016/j.ijrobp.2010.08.019

[10] Jensen, M.K., Koh-Banerjee, P., Hu, F.B., Franz, M. and Sampson, L. (2004) Intakes of Whole Grains, Bran and Germ and the Risk of Coronary Heart Disease in Men. The American Journal of Clinical Nutrition, 80, 1492-1499.

[11] Lui, R.H. (2007) Whole Grain Phytochemicals and Health. Journal of Cereal Science, 46, 207-219. http://dx.doi.org/10.1016/j.jcs.2007.06.010

[12] Traber, M.G. (1999) Vitamin E. In: Shils, M.E., Olson, J.A. and Shike, M., Eds., Modern Nutrition in Health and Disease, 10th Edition, Vol. 1, Williams \& Wilkins, Baltimore, 347-362.

[13] Gelmeza, N., Kıncal, N.S. and Yener, M.E. (2009) Optimization of Supercritical Carbon Dioxide Extraction of Antioxidants from Roasted Wheat Germ Based on Yield, Total Phenolic and Tocopherol Contents, and Antioxidant Activities of the Extracts. The Journal of Supercritical Fluids, 48, 217-224. http://dx.doi.org/10.1016/j.supflu.2008.11.002

[14] Hargrove, H., Greenspan, P. and Hartle, D.K. (2014) Nutritional Significance and Metabolism of Very Long Chain Fatty Alcohols and Acids from Dietary Waxes. Experimental Biology and Medicine, 229, 215-226.

[15] Dacie, S.T. and Lewis, S.M. (1993) Practical Haematology. Chap. 5, ELBS and Churchill, Levingston, London, 37-47.

[16] Beutler, E., Duron, O. and Kelly, B.M. (1963) Improved Method for the Determination of Blood Glutathione. Journal of Laboratory and Clinical Medicine, 61, 882-888.

[17] Yoshioka, T., Kawada, K., Shimada, T. and Mori, M. (1979) Lipid Peroxidation in Maternal Cord Blood and Protec- 
tive Mechanism against Activated Oxygen Toxicity in Blood. American Journal of Obstetrics and Gynecology, 135, 372-376.

[18] Chan, V.S. and Perlstein, L.D. (1987) Affinity Chromatographic Separation of Alpha-Fetoprotein Variants. Academic Press, New York, 71.

[19] Kaminska, J., Kowalska, M.M., Nowacki, M.P., Chwalinski, M.G., Rysinska, A. and Fuksiewicz, M. (2000) CRP, TNF $\alpha$, IL-1ra, IL-6, IL-8 and IL-10 in Blood Serum of Colorectal Cancer Patients. Pathology Oncology Research, 6, 38-41. http://dx.doi.org/10.1007/BF03032656

[20] Aramachi, T. (1989) Japan's Bioventures Today. Immuno-Biological Laboratories Company, Ltd., Japan, $370,831$.

[21] Esser, M.T., Bess, J.W., Suryanarayana, K., Chertova, E., Marti, D., Carrington, M., Arthur, L.O. and Lifson, J.D. (2001) Partial Activation and Induction of Apoptosis in CD4 $4^{+}$and $\mathrm{CD} 8^{+} \mathrm{T}$ Lymphocytes by Conformationally Authentic Noninfectious Human Immunodeficiency Virus Type 1. Journal of Virology, 75, 1152-1164. http://dx.doi.org/10.1128/JVI.75.3.1152-1164.2001

[22] Sinai, M.R., Uma Devi, S. and Yadav, S.S. (1978) Radiation Protection of Bone Marrow Lymphocytes by 2-Mercaptopropionylglycine (MPG). Experientia, 34, 1627-1628. http://dx.doi.org/10.1007/BF02034716

[23] Takabatake, T., Nakamoto, G. and Menovsky, A.A. (1997) Strong Reduction of Quasiparticle Scattering Rate with Gap Formation in CeNiSn. Physical Review B, 56, 8277-8281. http://dx.doi.org/10.1103/PhysRevB.56.8277

[24] Sarkar, S.R., Singh, L.R., Uniyal, B.P. and Bhatnagar, V.S. (1988) Radioprotective Effects of Liv.52 and Tissue-Reduced Glutathione (GSH) in Experimental Rats. The Bombay Hospital Journal, 4, 41.

[25] Sredini, B., Albeck, M., Kazimmersky, G. and Shalet, F. (1992) The Immunomodulator AS101 Administrated Orally as a Radioprotective Agent. International Journal of Immunopharmacology, 14, 613-619.

[26] Paranich, V., Cherevko, O., Frolova, N. and Paranich, A. (2000) The Effect of Wheat Germ Oil on the Antioxidant System of Animals. Likars'ka Sprava, No. 2, 40-44.

[27] Reddy, B., Hirose, Y., Cohen, L., Simi, B., Cooma, I. and Rao, C. (2000) Preventive Potential of Wheat Bran Fractions against Experimental Colon Carcinogenesis: Implications for Human Colon Cancer Prevention. Cancer Research, 60, 4792-4797.

[28] Steel, R.G.D. and Torrie, J.H. (1980) Analysis of Covariance. In: Steel, R.G.D., Ed., Principles and Procedures of Statistics: A Biometrical Approach, McGraw-Hill, New York, 401-437.

[29] Gridley, D.S., Pecaut, M.J., Miller, G.M., Moyers, M.F. and Nelson, G.A. (2001) Dose and Dose Rate Effects of Whole-Body Gamma-Irradiation: II. Haematological Variables and Cytokines. In Vivo, 15, 209-216.

[30] Wikins, R.C., Wikinson, D., Maharaj, H.P., Bellier, P.V., Cybulski, M.B. and McLean, J.R. (2002) Differential Apoptotic Response to Ionizing Radiation in Subpopulations of Human White Blood Cells. Mutation Research/Genetic Toxicology and Environmental Mutagenesis, 513, 27-36. http://dx.doi.org/10.1016/S1383-5718(01)00290-X

[31] Zhang, D.H., Cohn, L., Ray, P., Bottomly, K. and Ray, A. (2010) Transcription Factor GATA-3 Is Differentially Expressed in Murine Th1 and Th2 Cells and Controls Th2-Specific Expression of the Interleukin-5 Gene. The Journal of Biological Chemistry, 272, 21597-21603. http://dx.doi.org/10.1074/jbc.272.34.21597

[32] Abu-Sinna, G., Kafafy, Y.A., Nassar, A.Y. and Salman, M.A. (2005) Synergistic Effect of Bone Marrow Transplantation and Bradykinin Potentiating Factor Isolated from Venom on Thymus and Spleen of Sublethally Irradiated Guinea Pig. The Egyptian Journal of Radiation Science, 18, 249-255.

[33] Micke, O., Haidenberger, A., Auer, T., Egger, S., Seegenschmiedt, H.M., Hengster, P. and DeVries, A.F. (2005) Irradiation Causes Biphasic Neutrophilic Granulocyte Phagocytic Function. Strahlentherapie und Onkologie, 181, 313-318. http://dx.doi.org/10.1007/s00066-005-1346-2

[34] Ashry, O.M., Hussein, E.M. and Salama, S.F. (2009) Boosting of Antioxidant Defense by Interferon-Alpha in Irradiated Bone Marrow Transplantation Rats. The Egyptian Journal of Radiation Science, 22, 19-33.

[35] Nunia, V., Sncheti, G. and Goyal, P.K. (2007) Protection of Swiss Albino Mice against Whole-Body Gamma Irradiation by Diltiazem. The British Journal of Radiology, 80, 77-84. http://dx.doi.org/10.1259/bjr/41714035

[36] Omaima, M., Maha, G., Neveen, H. and Manar, A. (2013) Immunostimulatory Role of Panax Ginseng in Irradiated Bone Marrow Transplanted Rats. International Journal of Academic Research, 5, 115-123.

[37] Zarybnicka, L., Vavrova, J., Havelek, R., Tichy, A., Pejchal, J. and Sinkorova, Z. (2013) Lymphocyte Subsets and Their H2AX Phosphorylation in Response to in Vivo Irradiation in Rats. International Journal of Radiation Biology, 89, 110-117.

[38] Chew, B. and Park, J. (2004) Carotenoid Action on the Immune Response. Journal of Nutrition, 134, 257S-261S.

[39] Ma, X.H., Guo, W., Liu, X.P., Yin, T., Jia, X., Xiong, J., Zhang, H.P. and Wang, L.J. (2010) Effect of 60Co $\gamma$ Radiation on Mesenchymal Stem Cells (MSCs) Proliferation and Differentiation. African Journal of Microbiology Research, 4, 2161-2168. 
[40] Gong, F.L. (2003) Medical Immunology. Science Press, Beijing, 238-248.

[41] Bass, H., Mossmann, T. and Strober, S. (1989) Evidence for Mouse Th1- and Th2-Like Helper T Cells in Vivo. The Journal of Experimental Medicine, 170, 1495-1511. http://dx.doi.org/10.1084/jem.170.5.1495

[42] Adkins, B., Ghanei, A. and Hamiton, K. (1993) Developmental Regulation of IL-4, IL-2 and IFN- $\gamma$ Production by Murine Peripheral T Lymphocytes. The Journal of Immunology, 151, 6617-6621.

[43] Field, E.H., Rouse, T.M., Gao, Q. and Chang, B. (1997) Association between Enhanced Th2/Th1 Cytokine Profile and Donor T-Cell Chimerism Following Total Lymphoid Irradiation. Human Immunology, 52, 144-154. http://dx.doi.org/10.1016/S0198-8859(96)00291-1

[44] Han, S.K., Song, J.Y., Yun, Y.S. and Yi, S.Y. (2005) Gamma Irradiation Reduced IFN-Gamma Expression, STAT-1 Signal, and Cell-Mediated Immunity. Journal of Biochemistry and Molecular Biology, 35, 583-589.

[45] Chang, C.M., Limanni, A., Baker, W.H., Dobson, M.E., Kalinich, J.F. and Patchen, M.L. (1997) Sublethal Gamma Irradiation Increases IL-1 $\alpha$, IL-6, and TNF- $\alpha$ mRNA Levels in Murine Hematopoietic Tissues. Journal of Interferon \& Cytokine Research, 17, 567-572. http://dx.doi.org/10.1089/jir.1997.17.567

[46] Petit-Frère, C., Capulas, E., Lyon, D., Norbury, C., Lowe, J., Clingen, P., Christopher, J. and Green, M. (2000) Apoptosis and Cytokine Release Induced by Ionizing or Ultraviolet B Radiation in Primary and Immortalized Human Keratinocytes. Carcinogenesis, 21, 1087-1095. http://dx.doi.org/10.1093/carcin/21.6.1087

[47] Tsukimoto, M., Homma, T., Mutou, Y. and Kojima, S. (2009) 0.5 Gy Gamma Radiation Suppresses Production of TNF-Alpha through Up-Regulation of MKP-1 in Mouse Macrophage RAW264.7 Cells. Radiation Research, 171, 219224.

[48] Cachaço, A.S., Carvalho, T., Santos, A.C., Igreja, C. and Fragoso, R. (2010) TNF- $\alpha$ Regulates the Effects of Irradiation in the Mouse Bone Marrow Microenvironment. PLoS ONE, 5, e8980. http://dx.doi.org/10.1371/journal.pone.0008980

[49] Krishna, A. and Kumar, A. (2005) Evaluation of Radioprotective Effect of Rajira (Amaranthus paniculatus) Extract in Swiss Albino Mice. Journal of Radiation Research, 46, 233-239.

[50] Saada, H.N., Said, U.Z. and Mahdy, A.M. (2003) Effectiveness of Aloe Vera on the Antioxidant Status of Different Tissues in Irradiated Rats. Die Pharmazie, 58, 929-931.

[51] Said, U.Z. (2004) Neuroprotective Properties of Rutin in Radiation-Induced Biochemical Disorders in Brain of Rats. Arab Journal of Nuclear Sciences and Applications, 37, 223-231.

[52] Berdan, S., Nguyen, A. and Hassanein, D. (2011) Robo 4 Cooperates with CXCR4 to Specify Hematopoietic Stem Cell Localization to Bone Marrow Niches. Cell Stem Cell, 8, 72-83.

[53] Wang, Q., Jiang, J.Y. and Xie, S.S. (2002) Determination of Doxycycline in Serum by High-Performance Liquid Chromatography. The Chinese Journal of Clinical Pharmacology, 3, 119-201.

[54] Nakamura, T., Good, R.A., Yasumizu, R., Inoue, S., Oo, M. M., Mamashima, Y. and Ikehara, S. (2004) Successful Liver Allografts in Mice by Combination with Allogenic Bone Marrow Transplantation. Proceedings of the National Academy of Sciences of the United States of America, 83, 4529-4532.

[55] Lee, W.Y., Kang, M.I., Oh, E.S., Oh, K.W., Han, J.H., Cha, B.Y., Lee, K.W., Son, H.Y., Kang, S.K. and Kim, C.C. (2002) The Role of Cytokines in the Changes in Bone Turnover Following Bone Marrow Transplantation. Osteoporosis International, 13, 62-68. http://dx.doi.org/10.1007/s198-002-8339-5

[56] Kishimoto, T., Taga, T. and Akira, S. (1994) Cytokine Signal Transduction. Cell, 76, 253-262. http://dx.doi.org/10.1016/0092-8674(94)90333-6

[57] Tawara, I., Koyama, M. and Liu, C. (2010) Interleukin-6 Modulates Graft-Versus-Host Responses after Experimental Allogeneic Bone Marrow Transplantation. Clinical Cancer Research, 17, 77-88. http://dx.doi.org/10.1158/1078-0432.CCR-10-1198

[58] Singh, D.K., Li, L. and Porter, T.D. (2006) Policosanol Inhibits Cholesterol Synthesis in Hepatoma Cells by Activation of AMP-Kinase. Journal of Pharmacology and Experimental Therapeutics, 318, 1020-1026. http://dx.doi.org/10.1124/jpet.106.107144

[59] Brown, G.R. and Thiele, D.L. (2000) Enhancement of MHC Class I-Stimulated Alloresponses by TNF/TNF Receptor (TNFR)1 Interactions and of MHC Class II-Stimulated Alloresponses by TNF/TNFR2 Interactions. European Journal of Immunology, 30, 2900-2907. http://dx.doi.org/10.1002/1521-4141(200010)30:10<2900::AID-IMMU2900>3.0.CO;2-P

[60] Atkinson, K. (1990) Chronic Graft-Versus-Host Disease. Bone Marrow Transpl., 5, 69-98.

[61] De Rooij, D.G., Van de Kant, H.J., Dol, R., Wagemaker, G. and Van Buul, P.P. (2002) Long-Term Effects of Irradiation before Adulthood on Reproductive Function in the Male Rhesus Monkey. Biology of Reproduction, 66, 486-494. http://dx.doi.org/10.1095/biolreprod66.2.486 
[62] Ashry, O.M. and Hussein, E.M. (2007) Radioprotective Potency of Ginsengon on Some Haematopoeitic and Physiological Parameters in Irradiated Rats. The Egyptian Journal of Radiation Science, 20, 365-383.

[63] Adaramoye, O. A., Okiti, O. O. and Farombi, E. O. (2010) Dried Fruit Extract from Xylopia aethiopica (Annonaceae) Protects Wistar Albino Rats from Adverse Effects of Whole Body Radiation. Experimental and Toxicologic Pathology, 63, 635-643.

[64] Vinod, M., Jain, P., Verma, H., Kumar Gupta S., Sharma, V. and Thakur, R. (2012) An Overview on Natural Treatment of Systemic Lupus Erythematosus. Asian Journal of Pharmacy and Life Science, 2, 2231-4423.

[65] Zeinab, A., Khadiga, S., Abdel-Razik, H. and Eman, E. (2010) Effect of Carrot and Wheat Germ Oil Supplementation on Antioxidant Status of Rats Exposed to Benzene. Polish Journal of Food and Nutrition Sciences, 60, 175-181.

[66] Ibrahim, A.H., Osama, A., Samia. A. and Aziza, M. (2011) Evaluation of Radio Protective Effects of Wheat Germ Oil in Male Rats. Journal of American Science, 7, 664-673.

[67] Ehrenfeld, M., Blank, M., Shoenfeld, Y. and Hidvegi, M. (2001) AVEMAR (a New Benzoquinone-Containing Natural Product) Administration Interferes with the Th2 Response in Experimental SLE and Promotes Amelioration of the Disease. Lupus, 10, 622-627. http://dx.doi.org/10.1191/096120301682430203

[68] Hidvegi, M., Raso, E., Tomoskozi-Farkas, R., Lapis, K. and Szende, B. (1999) Effect of AVEMAR on the Immune Response of Mice. Immunopharmacology, 41, 183-186. http://dx.doi.org/10.1016/S0162-3109(99)00002-8

[69] Glynn, R.J., Ridker, P.M., Goldhaber, S.Z., Zee, R.Y. and Buring, J.E. (2007) Effects of Random Allocation to Vitamin E Supplementation on the Occurrence of Venous Thromboembolism: Report from the Women's Health Study. Circulation, 116, 1497-1503. http://dx.doi.org/10.1161/CIRCULATIONAHA.107.716407

[70] Huang, Z.R., Lin, Y.K. and Fang, J.Y. (2009) Biological and Pharmacological Activities of Squalene and Related Compounds: Potential Uses in Cosmetic Dermatology. Molecules, 14, 540-554. http://dx.doi.org/10.3390/molecules14010540

[71] Balk, B., Chung, M., Lichtenstein, A., Chew, P., Kupelnick, B., Lawrence, A., DeVine, D. and Lau, J. (2004) Effects of Omega-3 Fatty Acids on Cardiovascular Risk Factors and Intermediate Markers of Cardiovascular Disease. Immunopharmacology, 10, 36-44.

[72] Attila, S., Robert, C., Michail, I., Henry, D. and Allen, I. (2001) Nonlinear Behavior of Sinusoidally Forced Pyloric Pacemaker Neurons. Journal of Neurophysiology, 85, 1623-1638.

[73] Van Poppel, G. and Van den Berg, H. (1997) Vitamins and Cancer. Cancer Letters, 114, 195-202. http://dx.doi.org/10.1016/S0304-3835(97)04662-4

[74] Lee, I.M., Cook, N.R. and Gaziano, J.M. (2005) Vitamin E in the Primary Prevention of Cardiovascular Disease and Cancer: The Women's Health Study: A Randomized Controlled Trial. JAMA, 294, 56-65. http://dx.doi.org/10.1001/jama.294.1.56

[75] Sies, H., Stahl, W. and Sundquist, A. (1992) Antioxidant Functions of Vitamins. Vitamins E and C, Beta-Carotene, and Other Carotenoids. Annals of the New York Academy of Sciences, 669, 7-20. http://dx.doi.org/10.1111/j.1749-6632.1992.tb17085.x 